\title{
Obligation of the Parties, Lawyers and Judges
}

\author{
SANDOR UDVARY*
}

\begin{abstract}
The author analyses the newly codified civil procedure regarding its overall position towards the distribution of the obligations between the parties, their lawyers and the judges. Every civil procedure is balanced on the axis of this distribution, changing their inquisitorial or adversarial nature as the obligations vary. As the author illuminates, the new Code strikes a delicate balance between the elevated responsibilities of the parties and particularly their lawyers, and on the other side the courts having the burden of adjudicating a case in a fair and just way within reasonable time.
\end{abstract}

Keywords: civil procedure, obligation of judge, obligation of party, preclusion, responsibility of attorney

\section{THE CODIFICATION OF CIVIL PROCEDURE}

The "obligation" of the author is to present the newly codified Hungarian Code of Civil Procedure from the viewpoint of the rights and duties of the parties, lawyers and judges. Professor Uzelac gave a very interesting presentation about their results at the European Law Institute, ${ }^{1}$ whereas this paper describes the forthcoming Code. The Hungarian Code was under public and administrative debate at the time of the presentation and after a parliamentary debate and several amendments there it was passed into law: Act CXXX of 2016. Some critics would say that this upcoming Code is ready for breaking. It will be known in an instant, because unlike substantive law, which needs years to develop and, even then, may be bent by interpretation, procedural law will show its errors and flaws in minutes, sometimes literally, after entering force and have space for interpretative amends. Thus, the author can only hope that this piece of legislation is good enough and not flawed beyond repair.

In general terms, the obligation of parties, lawyers and judges need to be balanced. Since Franz Klein and his concept of social function of civil procedure, ${ }^{2}$ it is rarely stated on a theoretical level that any state might want to return to the liberal traditions of the civil procedure. However, in Hungary there was a dreadful experience with the centralized experiment of civil procedure. ${ }^{3}$ The neighbouring state: Austria, which is close to our legal tradition might show a good middle stance - aurea mediocritas. Furthermore, there are constitutional and international requirements, most of them not present a century ago, which narrow the path of any legislator. These constitutional guarantees stem from international agreements or internal tradition. These regulate fundamental procedural safeguards and are indispensable to a modern procedural system as framework in a globalizing world; where

* Associate professor, Károli University, School of Law, head of the Civil Procedure Department, udvary.sandor@kre.hu

1 Conference on the New Hungarian Civil Procedure Act and the Development of European Rules of Civil Procedure, European Law Institute - UNIDROIT Hungarian Academy of Sciences Institute for Legal Studies - Hungarian Ministry of Justice - National Office for the Judiciary 30-31 May, 2016, Budapest $<$ https://www.europeanlawinstitute.eu/fileadmin/user_upload/p_eli/Events/HU_ UNIDROIT AGENDA.pdf $>$ accessed 6 June 2017.

2 Klein (1891), on his impact on continental civil procedure, see: Walter (2008) 101-10.

3 Gyekiczky (2003); Gyekiczky (2006); Gyekiczky (2016). 
these guarantees (access to justice, equality of rights, fair and public hearing etc.) serve the citizens and companies as safety net. International standards given by the European Convention on Human Rights, the ever growing EU law and its constantly evolving interpretations would effectively prevent a returning to old totalitarian ways of rendering civil justice. These regulations and rules effectively narrow the path of the legislator to renew any Code to a theoretically appealing fashion - if that solution would practically violate any internationally recognized or constitutional right. An example from the economic analysis point of view is that the judicial system, a constitutional institution, does not need to be profitable and might be overburdened by small cases which are too small for the invested public money into the working hour of a judge. Still, legislator might not exclude judicial remedy under, say 1 million HUF (3300 USD), or 3 million HUF (10750 USD) but has to find other ways. Legislator resolved this by the concept of small claims procedure. Professor Varga criticized this idea as it breaks the required unity of the Code ${ }^{4}$ and coupled it with the mandatory order for payment issued by the civil law notary. Perhaps the system will soon change and the small claims procedure will be dropped - in accordance with Prof. Németh's and Varga's concept of all the most unified tracks of civil justices, ${ }^{5}$ which was accepted by the new Code. The important lesson is that there is a way to find a solution for the legislative aim to lessen the burdens of judicial system from small claims litigation.

\section{SEVERAL OBLIGATIONS OF THE COURTS UNDER THE NEW CODE}

2.1. This article focuses on a strict description of the renewed Code and focus starts with the judge and their obligations during the procedure.

According to $\S 4$ of the original draft and $\S 3$ of the T/11900 Bill and the final Code, ${ }^{6}$ the court and the parties must endeavor that all factual circumstances and evidence be present in such timely manner that the controversy be tried in possibly one session of the court. This principle, a fundamental obligation, of trial-concentration binds the court and the parties. This is unfolded in particular regulations of offering the evidence, the form of claim, the restrictions in amending the claims etc. However, as the principles provide an interpretative framework for the particular rules, they all have to be interpreted in accordance with this principle. Thus when procedural circumstances would allow final decision in one session but the judge fails to decide seems to be a violation of that principle. There are not much about sanctions in the Civil Procedure, but the Act on the Judges Status and their Remuneration indirectly covers the sanctions for constant unlawful activities of the judge.

There is still one novelty in the principal chapter of the Code. According to $\S 6$ in the Bill ( $\$ 7$ in the former draft, the text unchanged), the court, in order to enforce the concentration of the litigation, by means and tools set out in this Act shall contribute that the parties fulfill their procedural obligations. It is known as "substantive management of trial" and the idea initially triggered some resistance amongst the judges. Again, it can be seen that the court and the parties hold hand in that obligation. Interestingly, it is not the

4 Varga (2008) 9-14.

5 Varga (2014) 19-49, 36-41.

$6<$ http://www.parlament.hu/irom40/11900/11900.pdf > accessed 6 June 2017. 
court's obligation, mentioned directly in this phrase, but the court's assistance that helps to enable the parties to fulfill their obligation. This phrasing is slightly confusing as it is clear that this is a full-fledged obligation on the judicial side and as the first mentioned principle, it will also be unfolded in particular rules.

Two more general rules of the first draft (not principles) deserve closer attention. The equality of arms $(\$ 12)^{7}$ was forged in the criminal procedure but Constitutional Court's interpretation related this to civil procedure as well. The court is obligated to let the parties know every evidence, plea and petition and make a statement regarding to them. It is rather the natural consequence of the contradiction principle, which is so inherent, that it is never mentioned, that the opposing parties be entitled to refer to each other's position. ${ }^{8}$ This is now an expressis verbis obligation of the court strengthen procedural fairness.

Information duty is the last general obligation of the court. This is no real novum, as it is in the effective code - the court must inform the unrepresented party about their procedural rights and obligations and the possibility of state-financed legal representation ( $§ 14$ of the Draft, rephrased in $\S 111$ of the Bill and the Act).

2.2. Rules will not be mentioned in detail which confer the obligation of ex officio observation and action to the court, such as finding the lack of their subject-matter jurisdiction or that the territorial jurisdiction is lacking. They were known regarding the jurisdiction, the status of the parties and their proper representation, the costs of the procedure, forged documentary evidence, all of which factors may and must be observed ex officio and proper action be taken by the court. There is a slight increase in the number of occasions of ex officio actions, partially the result of the EU legislation and court decisions. The relevant EU legislation is the consumer-protection rules, which are interpreted by the European Court of Justice in a way that 'The national court is required to examine, of its own motion, the unfairness of a contractual term where it has available to it the legal and factual elements necessary for that task. Where it considers such a term to be unfair, it must not apply it, except if the consumer opposes that non-application. That duty is also incumbent on the national court when it is ascertaining its own territorial jurisdiction. ${ }^{9}$ This is only the obligation of the courts in consumer cases but this interpretation reaches well beyond the traditional ex officio examination of the territorial jurisdiction as it contains the examination of a substantive contractual term.

There is one field where the duties of the court have been eased. The current rules mandate the court to decide over the procedural costs ex officio. According the draft of the new Code ( $\$ 89-90)$, and similarly in the Bill and the Act $(\$ \S 80-81)$, the party may move for the reimbursement of their costs by way of statement of expenses and the court must decide only if such statement was filed and within its boundaries. According to expectations, that will substantively ease the procedural burden on the courts - putting the job of calculating and verifying the costs to the shoulder of the parties and their lawyers.

7 Caveat! After the presentation, the T/11900 Bill dropped this explicit rule, but rephrased its content in $\S \S 110-112$. Therefore we keep this argumentation in the Article, with this caveat.

8 We see that position confirmed in the fact that the legislator later rephrased these regulations into the particular rules of the procedure ( $\S 110-112$ of the Bill) and left the principal requirement to where it belongs: the jurisprudence.

9 Pannon GSM v Sustikné Győrfi Erzsébet, Case C243/08. 


\section{OBLIGATIONS OF THE PARTIES}

3.1. Parties' rights and obligations will also be slightly amended in the new Code. First of all, recalling that the principal rules contained joint obligations for the court and the parties, parties have a responsibility to support the procedure when the court is required to ensure several procedural rights. Hence, the Courts and parties have the joint obligation of trialconcentration and the substantive trial management, where the division of responsibility remains to be determined by the proceeding courts in the future. Further principles binding the parties are the principle of supporting the procedure and the obligation of veracity. It simply states that the parties are obligated to support the concentrated procedure. This is aimed at the defendant for the majority of cases as it is in their interest to delay the case, but sometimes these roles might change (not only in the case of a counter-claim) and this principle also binds the plaintiff. The obligation of veracity ( $\$ 4$ of the Bill) binds the parties - they have to present their factual allegations and any references to the facts in accordance with the truth. However, the legal representative, is not bound by this principle and this will be returned to later on. The principle of bona fidei procedure not only binds the parties but all procedural actors (representatives, witnesses, experts) and while its content is not extracted, the violation of this principle shall be a fine and the awarding of related costs. The courts, relying to their present interpretation, carve out the content of this principle.

$\S 10$ of the draft ( $\$ 4$ of the Bill in the same way) is the last but perhaps most important fundamental "obligation" of the parties. It states that it is the burden of the parties to produce the relevant facts and the supporting evidence. The principle of producing the relevant material of the case is different from the extreme adversarial principle, as there are several exemptions given by law, where the court may order taking evidence on her own motion. This is far from the socialist tradition of full-fledged ex officio substantiation and as a theoretical remark, it is no burden or obligation of the parties, rather their interest to produce the material, as a certain Ferenc Kobler clarified ${ }^{10}$ over 100 years ago and Tamás Éless resurfaced this right before the start of the codification. ${ }^{11}$

The most important obligation of the parties is related to the procedural steps to be taken. The structure of the procedure has to be created sequentially, like bricks are laid on one another, and the obligations of the parties are the coupling between these steps. After the claim having been filed, the defendant is obligated, rather interested, to answer this claim. The rules of this answer are important details, and but the next step in the procedure is the option between answering or failing to answer and in the latter case the further consequences and sanctions of the default. Now these steps define the procedure and even though they might be placed into several structural framework (for example unified or split system of trial), the fundamental pattern is surprisingly constant: allegations on plaintiff side, answer from the defendant, allegations again and denial of the answer from the right, new answers from the left... This pattern could continue on indefinitely but the constitutional and practical necessity of rendering a final decision should break the loop at the point of 'maturity for decision on the merit'. Naturally the choices of the legislator define the form of these actions, that they may be taken orally or must be written (electronic communication), that some may be taken during the whole procedure, others will be waived if a certain deadline is missed and so on. Still, look backwards to the past, it can be seen that while the building of the actual procedure surely has changed, the bricks are still quite the same.

10 Köbler (1901).

11 Éless (2013) 613-16. 
3.2. How is that building shaped in the new Code? As a reminder, discussions of the procedure of the general first instance court, the Regional Court (while for the cases of local courts, these requirements are eased to some extent. First of all, written part of the procedure is somewhat strengthened, since claim and answer must be filed with the court in writing. This has to be coupled with the general rule of mandatory legal representation and the obligation of lawyers to communicate with the court in electronic ways. The following picture appears where there is at least one round of document exchange of the parties, where they have to meet strict formal requirements set out in the code and they have to do it in electronic way. The strict formal requirements requires the statement of claim to be divided into introductory part with the court and the personal information on the parties in it; a substantive part, where the definite claim must be stated with great accuracy. The factual basis of the case must be stated along with the legal background of the stated claim and all the aforementioned factors must be supported by the relevant documentary evidence, or the offering of the necessary evidence. The closing part should contain data related to the jurisdiction of the court, the capacity of the parties, the representation, the fees etc. and there are several appendices that must be attached to the claim. The answer of the defendant - which again must be submitted in a written form - must contain relevant defense in the corresponding order.

After this round of document exchange, the court shall decide whether a preparatory trial needs to be held or another round of document exchange is necessary. The court must hold a preparatory trial if it any of the parties have move for it.

3.3. The most onerous burden of the parties shall be the complete statement of facts and legal background of the claim together with the production of evidence. Virtually all experts have agreed that split system of trial, and the obligation of the parties to fix the boundaries of their controversy must be so regulated that the trial on the merit should deal with the evidence and legal issues of the case and no amendment, modification of pleading be allowed during that second phase. ${ }^{12}$

Where honest difference between professional opinions occurs is the structure of preparatory trial and the scope of parties' obligation thereof. The experts' commission from the Minister of Justice found that, besides pleading in written form, the oral preparatory trial should take place in quick succession, where the defendant would be obligated to present their defenses, procedural objections first, so the court could examine the rejection of the claim. During this preparatory trial, with the active participation of the judge, both parties would fix the boundaries of the trial, which then could turn into the meritorious issues. Claims and substantive defenses could not be amendable later. During the trial, the parties, on merit, would be allowed and obligated to propose and present their evidence and necessary legal reasoning, besides their original reasons presented in their claims and substantive defenses. ${ }^{13}$ Thus, the experts commission found little place for preclusion, only during the trial on the merits the timely fashion of the procedure would allow for exclusion of delayed evidence.

The draft earlier under administrative debate has taken another course, with the clear concurrence of the judicial branch and has somewhat backed down. The Bill now contains eased rules. The first draft of the Code contained an explicit obligation of the parties to state all necessary facts and propose their evidence in their claims and defenses during the

12 See: Éless and Döme (2014) 50-78.

13 Éless and Döme (2014) 50-78. 
preparatory trial. A categorical rule declared any fact stated or evidence proposed later, after the preparatory stage to be null and void. That was categorical preclusion that, according to the expectations, would serve the timely administration of justice. However, there is a rule in the draft, which allows stating new facts or proposing new evidence only under certain circumstances, essentially in the case of permissible amendment of pleading ( $\$ 227$ of the Draft on Subsequent Production of Evidence). All these three parts effectively curtailed presentation of factual elements to the preparatory stage, thus leaving the trials on the merit only with the taking of that evidence and deliver a decision based on that.

However, due to internal and external critiques, the categorical rule to declare any later proposed fact and evidence null and void, has been dropped and the Bill of the Code contains no such rule. Thus, now the parties have the obligation of presenting their facts and evidence in their claim and defenses to the possible extent - that is a clear remaining obligation on their side. Still, the narrow rule of allowing statement of facts and evidence in the second (meritorious) phase, stands. The explicit preclusionary rule has been dropped.

3.4. The author would like to take a moment from the narrative of the rules and offer an interpretation with a suggestion. The author was a strong supporter of preclusion inserted into the Code, as a disciplined procedure needs such sanctions where the delay or failure to present facts and evidence results in decision based on the existing data. The author had always suggested that the rules be flexible enough to avoid unwanted consequences. It was suggested that an escape route should be incorporated into the meritorious phase so that the party be allowed to present fact or evidence if they show that there is no fault on their side to present this in the earlier phase e.g., the fact and its evidence was unknown to them and even with exercising due diligence they could not have known the fact, offered or presented that evidence. Of course with that exception, a possible delay has been created in the whole procedure, but when justice so requires, the Code should allow the presentation of evidence.

\section{RESPONSIBILITY OF THE LAWYERS}

4.1. Lawyers as professional representative of the parties are the usual, though not indispensable, part of the procedure. It is no coincidence that the mandatory representation was considered constitutional by the Constitutional Court as it improves the quality of the administration of justice, in general. ${ }^{14}$ Thus, the Code tries to clarify the somewhat blurred picture of mandatory representation - it shall be the main rule, with the exception of the cases of local courts as first instance courts. Thus, in cases brought before the local courts and during their appellate procedure, the party should be free, not be obligated, to mandate professional representative. The personal scope of mandatory representation will also be narrowed. Only attorneys-at-law shall have license to represent before the courts, with the minor exception of persons with bar exam in their own cases or the public prosecutor. Thus might bar the now representing in-house-counsels out of the court, which might overburden the Bar Associations. A relevant portion of the cases initiated by or against administrative agencies or companies are legally represented by the in-house-counsels (with a bar exam the same qualification as attorneys) and it is unclear, how the attorneys shall take over these tasks. The Legal Department of Treasury (Kincstári Jogügyi Igazgatóság) should ease the problem as all state-agencies will be represented by this entity, but companies' attorneys may still pose a practical problem. Modifications in the overall picture of legal professions 
since conference ${ }^{15}$ has affected this picture. According to the present concept of the legislator, in-house-counsels who provide services of representation before the court (of their employee) shall be obligated to join the Bar Association as employed attorneys. Thus, the limitation of representation to attorneys shall not have a dramatic effect on the legal profession.

4.2. The Code will broaden the scope of mandatory representation and there will be exception, changing the current rule. Is there any elevated requirement against lawyers? First of all, the burdens on the parties shall be conveyed to the shoulders of the lawyer, through a contract for legal services, which the lawyer is free to undertake. Still, if accepted, they are professionally liable, with the threat of monetary compensation, for doing all necessary procedural actions in the best interest of the party. Professional liability is not aggravated, though the obligations to carry out are more numerous and on more occasions have strict deadline.

4.3. One more general remark is that the level of orality in the procedure has dropped somewhat, so the level of written communication, especially the electronic communication will be increased. E-litigation is coming, with delays, and this communication method is written (with the exception of CCTV trial). It needs tools and proficiency, that the ordinary clients do not have, and it is mandatory for the legal representatives and companies. As legal representation is mandatory in general, the normal ways of communication seems to be exceptional rather than the rule. The statistics still show that vast number of cases should start before the local court, where neither legal representation, nor e-communication is mandatory. However, the aim of the legislator is to strongly promote this supposedly fast method of communication. It will necessitate all efforts on the lawyers' society's side to live up to the expectations and make good use of these technologies.

The exact reason for mentioning this is the very strict sanction of failing to meet the requirements. Should e-communication be mandatory or freely undertaken by the party, the failure to send any submission, motion to the court in the proper form would be sanctioned by nullity. If the party (or their lawyer) fails to send any submission to the court in electronic means, or by sending it so, fails to meet the particular many technical requirements, the submission must be deemed null and void and the party and his representative is in default. Naturally, it can be understood that no system may be made exclusive, if its use may be freely evaded. It is a simple necessity that the mandatory use of the system be sanctioned. However, besides the possible rise in the numbers of professional liability cases against the lawyers, the courts will face a situation, where they will hold a document in their hand, null and void by the force of the law owing to the possible technical failings of the lawyer, but the document would facilitate justice. Clearly, they have to ignore it by the direct order of the law, just as Antigone should have ignored the divine order and leave his brother unburied. Of course, there is no intention to foresee such tragedies, but the collision of ethical and legal regulations might occur in such cases. The law has to prevail.

4.4. It has to be admitted that not all lawyers bear the qualities of a Greek hero of a tragedy but they need to be sanctioned and disciplined. For that, the draft of the Code reserves the sanction of mala fidei behavior of the representative. Thus, if the lawyer violates their duty of veracity, they wantonly or neglectfully tells untrue or denies true fact, refers to manifestly unfounded evidence or untruly refers to facts, they have to be fined, if the act was their fault. Now, that is nothing but reservation of the former mala fidei 
procedural act, renamed to the violation of veracity. Still, the underlying theory has changed, while the general prohibition of mala fidei procedural acts remained, but without particular examples. The judicial practice will tell its content. This theoretical change might be problematic from one point, though, if unamended. It has been seen that the obligation of veracity binds the parties exclusively. Here, the violation of this principle is sanctioned when the party or their representative commits the act. Thus, the personal scope of the underlying principle, of which's violation is to be sanctioned does not cover the representative. If court interpretation may not jump this gap over, the author is rather sure that the legislator will have to amend the rule, for the aim of disciplining liar lawyers (Is it a coincidence how similar the two words sound?) is legitimate on the side of the lawmaker. Neither those lawyers deserve protection, who lie by mandate from the party. If the legal representative reflects the allegations of their client, they will have to defend themselves with regular attorney practices. Unethical elements should be weeded out of the bar association.

To summarize this paper, the obligations of the parties, their lawyers and the courts have been reshaped by the changes in the structure of the procedure and the intensified written form. Practice will show whether the stricter rules will support the timely resolution of controversies, or be counterproductive, as some honest critiques state. For the sake of the law abiding citizens, it can only be hoped that the civil justice system will apply these rules to further the constitutional goals and guarantees of the citizens, for their constant wellbeing.

\section{LITERATURE}

Gyekiczky, T., 'Törvény születik. Adalékok az 1952. évi polgári perrendtartás keletkezésének történetéhez. (Egy levéltári kutatás előzetes tapasztalatai).' (The birth of an act of law. Additional pieces of information on the history of the elaboration of the 1952 Code of Civil Procedure. /The prior experience of an archival research/) in Wopera, Zs. (ed), 50 éves a polgári perrendtartás. (Novotni Kiadó 2003).

Gyekiczky, T., Helyzetjelentés (Levéltári iratok polgári eljárásjogunk történetéböl) (Progress report/ Archival documents from the history of our civil procedural law/) (Gondolat 2006).

Gyekiczky, T., Beforditva - Levéltári iratok a jogpolitikáról, a biróságokról, és a biráskodás lehetöségeiröl a „Kádár” korszakban (1958-1990) (Turning inwards - Archival documents on legal policy, courts and the possibilities of adjudication during the Kádár era (1958-1990) (Patrocinium 2016).

Éless, T., 'Szerkezeti alapkérdések a polgári per kapcsán' (Structural Fundamental Issues Regarding the Civil Litigation), (2013) 10 Magyar Jog 614-15.

Éless, T. and Döme, A., 'Alapvetések a polgári per szerkezetéhez' (Fundamental Issues of the Structure of the Litigation) in Németh, J. - Varga, I. (eds), Egy új polgári perrendtartás alapjai (The Foundations of a New Civil Procedure) (HVG-ORAC 2014) 50-78.

Klein, F.: Pro futuro: Betrachtungen über Probleme der Civilproceßreform in Österreich, (Deuticke 1891).

Köbler, F., Az állitási érdek szabályai: tekintettel a magyar polgári perrendtartás törvényjavaslatára, (Interest of Allegation of Facts With Regard to the Bill of Civil Procedure) (Franklin-Társulat 1901).

Udvary, S., 'Rules of Representation in the Light of the Constitutional Court's Decisions' in Papp, Zs. (ed), The Hungarian Civil Procedural Law in the '90s and the EU Law Harmonisation (ELTEÁJK 2003) 328-45.

Varga, I., 'Úton az egységes európai peres eljárás felé? - Észrevételek az első mérföldkőnek szánt „Bagatell Rendelet”-hez.' (On the Way to the Unified European Civil Procedure? - Remarks to the First Milestone, the Bagatelle-Regulation) (2008) 5 Európai Jog 9-14. 
Varga, I., 'Egység és sokféleség a perrendi kodifikációban - egy új polgári perrendtartás szabályozási előkérdései' (Unity and Diversity in the Procedural Codification - The Regulatory Preliminary Issues of a New Civil Procedure) in Németh, J. and Varga, I. (eds), Egy új polgári perrendtartás alapjai (HVG-ORAC 2014).

Walter, H. R., 'Die Ideen Franz Kleins und ihre Bedeutung fur die Entwicklung des Zivilprozessrechts in Europa' (2008) 25 Ritsumeikan Law Review 101-10. 